\title{
The Formation of an R-prime Carrying the Fraction I Dehalogenase Gene from Pseudomonas putida PP3 using the IncP Plasmid R64.44
}

\author{
By JOHN R. BEECHING, ANDREW J. WEIGHTMAN† AND \\ J. HOWARD SLATER* $\ddagger$ \\ Department of Environmental Sciences, University of Warwick, Coventry CV4 7AL, U.K.
}

(Received 10 November 1982; revised 7 January 1983)

\begin{abstract}
Plasmid R68.44 was transferred to Pseudomonas putida PP3 at a frequency of approximately $10^{-6}$. In the new strain, $P$. putida PPW1, the plasmid, designated pUU1, lost a $2.0 \mathrm{~kb}$ fragment corresponding to IS21 which had previously been implicated in enhanced chromosome mobilization, but gained between 3.4 and $5.7 \mathrm{~kb}$ of DNA. Plasmid pUU1 was used to mobilize the fraction I dehalogenase gene at a low frequency of approximately $10^{-10}$ into another strain of $P$. putida. The R-prime plasmid, designated pUU2, contained an additional 9.2 to $11.0 \mathrm{~kb}$ fragment which carried the fraction I dehalogenase.
\end{abstract}

\section{INTRODUCTION}

Pseudomonas putida strain PP3, isolated by Senior et al. (1976) as a result of its acquired capacity to grow on 2,2-dichloropropionic acid (22DCPA; the herbicide Dalapon) and 2monochloropropionic acid (2MCPA), has been shown to contain two dehalogenases (Weightman et al., 1979; Weightman \& Slater, 1980). Dehalogenases, or alternatively halidohydrolases, catalyse the hydrolytic removal of halides from halogenated alkanoic acids, particularly chlorinated acetic and propionic acids (Goldman et al., 1968; Little \& Williams, 1971; Slater et al., 1979). So far, a limited range of microbial genera have been grown on halogenated alkanoic acids (Slater et al., 1979; Berry et al., 1979), although some evidence suggests that a greater number of different bacterial species with dehalogenating capabilities can be isolated from environments which have been challenged by the presence of chlorinated alkanoic acids (Burge, 1969; Hardman \& Slater, 1981) compared to those from unchallenged environments.

We are interested in the mechanisms of transfer of genes coding for catabolic functions in natural populations of loosely or closely associated communities (Slater 1978; Slater \& Godwin, 1980; Slater \& Bull, 1982). It would be of particular interest to know how the dehalogenase gene (or genes) of $P$. putida PP3 may be transferred initially to other pseudomonads and ultimately to other genera by mechanisms involving plasmid transfer. We have argued (Hardman \& Slater, 1981) that the plasmid-mediated transfer of dehalogenase genes might explain the increased occurrence of different bacteria possessing dehalogenases after challenging the mixed microbial flora with halogenated alkanoic acids. Furthermore, plasmid-mediated mobilization of dehalogenase genes provides a possible mechanism for the evolution of strains carrying multiple dehalogenase genes (Hardman \& Slater, 1981), and recent evidence suggests that the dehalogenase genes in a number of soil bacteria are plasmid-borne (Kawasaki et al., 1981, 1982; D. J. Hardman, P. C. Gowland and J. H. Slater, unpublished observations).

† Present address: Département de Biochimie Médicale, Université de Genève, Centre Médical Universitaire, 1211 Genève 4, Switzerland.

$\ddagger$ Present address: Department of Applied Biology, UWIST, King Edward VII Avenue, Cardiff CF1 3NU, U.K.

Abbreviations: MCA, monochloroacetic acid; DCA, dichloroacetic acid; 2MCPA, 2-monochloropropionic acid; 22DCPA, 2,2-dichloropropionic acid. 
Plasmid R68.44 is a derivative of R68 which exhibits enhanced chromosome-mobilizing ability (Haas \& Holloway, 1976) and has been shown to be physically identical to the more stable R68.45 (Leemans et al., 1980). R68.44 differs from R68 by a $2.12 \mathrm{~kb}$ duplicated region which is correlated with the possession of enhanced chromosome-mobilizing ability (Riess et al., 1980; Leemans et al., 1980; Willetts et al., 1981).

In this paper, we report the introduction of plasmid R68.44 (Haas \& Holloway, 1976) into $P$. putida PP3, its structural modification in this strain and the mobilization of chromosomal DNA carrying a dehalogenase gene into another strain of $P$. putida.

\section{METHODS}

Bacterial strains and maintenance. Pseudomonas putida PP3 $\left(2 \mathrm{Mcpa}^{+} 22 \mathrm{Dcpa}^{+} \mathrm{Ap}^{\mathrm{s}} \mathrm{Km}^{\mathrm{s}} \mathrm{Sm}^{\mathrm{s}} \mathrm{Tc}^{\mathrm{s}}\right)$ was obtained as previously described (Senior et al., 1976). Pseudomonas putida PaW340 (2 Mcpa- 22Dcpa ${ }^{-}$Trp $^{-}$ $\mathrm{Ap}^{\mathrm{S}} \mathrm{Km}^{\mathrm{S}} \mathrm{Sm}^{\mathrm{R}} \mathrm{Tc}^{\mathrm{S}}$ ) was kindly provided by Dr P. A. Williams (University College of North Wales, Bangor). Pseudomonas aeruginosa PAC174 (2Mcpa $\left.\mathrm{Mc}^{-} 22 \mathrm{Dcpa}^{-} \mathrm{Lys}^{-}\right)$containing plasmid R68.44 $\left(\mathrm{Ap}^{\mathrm{R}} \mathrm{Km}^{\mathrm{R}} \mathrm{Tc}^{\mathrm{R}}\right)$ was kindly provided by Professor P. H. Clarke (University College, London). Pseudomonas aeruginosa PAO1162 (leu-38 rmo11) (Dunn \& Holloway, 1971) was kindly provided by Professor K. N. Timmis (University of Geneva, Switzerland). A spontaneous rifampicin-resistant derivative of PAO1162, designated $P$. aeruginosa PAU2, was selected on nutrient agar containing rifampicin at $250 \mu \mathrm{g} \mathrm{ml}^{-1}$. The parent and derivative strains capable of growing on 2MCPA were grown on defined medium containing 2MCPA (Slater et al., 1979) supplemented, where appropriate, with amino acids $\left(25 \mu \mathrm{g} \mathrm{ml}^{-1}\right)$, ampicillin $\left(50 \mu \mathrm{g} \mathrm{ml}^{-1}\right)$, kanamycin $\left(50 \mu \mathrm{g} \mathrm{ml}^{-1}\right)$, tetracycline (150 $\left.\mu \mathrm{g} \mathrm{ml}^{-1}\right)$, rifampicin $\left(250 \mu \mathrm{g} \mathrm{ml}^{-1}\right)$ and streptomycin $\left(750 \mu \mathrm{g} \mathrm{ml}^{-1}\right)$. The other strains were maintained on nutrient agar (Oxoid) supplemented as necessary with drugs at the above concentrations. King's A and B media were made as described by King \& Phillips (1978).

Measurement of dehalogenase activity. The dehalogenase activity was determined in organisms grown in medium containing 2MCPA at $0.5 \mathrm{~g} \mathrm{Cl}^{-1}$. The cultures were incubated overnight at $30^{\circ} \mathrm{C}$ on an orbital shaker rotating at 200 r.p.m. Late-exponential phase cultures were harvested by centrifugation at $5000 \mathrm{~g}$ for $15 \mathrm{~min}$, and washed and resuspended in $0.02 \mathrm{M}$-Tris/sulphate buffer, $\mathrm{pH} 7.9$. Crude cell-free extracts were prepared by two passages through a French pressure cell (Aminco International) at $83 \mathrm{MPa}$. The remaining whole organisms and cell debris were removed by centrifugation at $30000 \mathrm{~g}$ for $45 \mathrm{~min}$.

Dehalogenase activity in the cell-free extract against MCA, DCA, 2MCPA and 22DCPA was determined as previously described (Weightman \& Slater, 1980). The assay depended on measuring free chloride ion release in a Marius Chlor-O-Counter (F. T. Scientific, Tewkesbury) as previously described (Slater et al., 1979). Protein concentration of the extracts was estimated by the Biuret method using BSA as the reference protein. Enzyme specific activities were expressed as $\mu \mathrm{mol}$ substrate converted $\min ^{-1}$ (mg protein $)^{-1}$.

$P A G E$. The two dehalogenases of $P$. putida PP3 were separated and identified in derivative strains by an analytical discontinuous PAGE technique as described by Weightman \& Slater (1980) and Hardman \& Slater (1981).

Plasmid transfer and chromosome mobilization. A modified membrane mating technique due to Hedges \& Jacob (1977) was used. The parent strains were grown in either LB broth (Miller, 1972) or defined medium containing 2MCPA and supplemented as appropriate. Samples of mid-exponential phase donor culture ( $5 \mathrm{ml}$ ) or maximum population phase recipient culture $(5 \mathrm{ml})$ were centrifuged and each resuspended in $5 \mathrm{ml}$ of $0.1 \mathrm{M}$-phosphate buffer $\mathrm{pH} 7 \cdot 0$. The suspensions were mixed and vacuum-filtered through a sterile $0.45 \mu \mathrm{m}$ pore size membrane filter (Millipore). The filter was transferred to the surface of an LB agar Petri dish and incubated at $30^{\circ} \mathrm{C}$ for $6 \mathrm{~h}$. The membrane was transferred to a sterile test tube and the organisms resuspended in $2.5 \mathrm{ml} 0.1 \mathrm{M}$-phosphate buffer $\mathrm{pH} 7 \cdot 0$. The suspension was serially diluted in $0.1 \mathrm{M}$-phosphate buffer and samples $(0.1 \mathrm{ml})$ of appropriate dilutions spread on suitable selective media to screen for transconjugants.

Screening for the presence of plasmid DNA. The method developed by Wheatcroft \& Williams (1981) was used.

Plasmid DNA isolation for restriction endonuclease analysis. The method of Birnboim \& Doly (1979) was used.

Plasmid DNA digestion by restriction endonuclease. The restriction endonucleases EcoRI, HindIII, Pst I and $S m a I$ were used in accordance with the manufacturer's instructions (Boehringer, Mannheim). After $2 \mathrm{~h}$ the digestion was terminated by heat inactivation at $65{ }^{\circ} \mathrm{C}$ for $10 \mathrm{~min}$. The resulting DNA fragments were separated by electrophoresis in horizontal $0.7 \%(\mathrm{w} / \mathrm{v})$ agarose gels in TB buffer containing $89 \mathrm{~mm}$-Tris, $2 \cdot 5 \mathrm{~mm}$-EDTA and $89 \mathrm{~mm}$-boric acid. The gels were run at 30 to $60 \mathrm{~mA}$ for $16 \mathrm{~h}$, stained with ethidium bromide and photographed. The plasmid DNA fragments were sized by comparison with the DNA fragments produced by a double EcoRI and HindIII restriction endonuclease digest of $\lambda$ DNA (Boehringer Mannheim). The standard sizes for the $\lambda$ fragments were taken from Southern (1979).

Transformation. This was performed as described by Bagdasarian \& Timmis (1981).

Materials. All materials for the growth and enzyme assays were of the highest commercially available purity as described previously (Slater et al., 1979; Weightman \& Slater, 1980), as were the materials used for the plasmid analyses. 


\section{RESULTS}

\section{The introduction of plasmid R68.44 into P. putida PP3}

Plasmid R68.44 was transferred by conjugation to $P$. putida PP3 in a membrane mating with $P$. aeruginosa PAC174, selecting for transconjugants on defined medium containing 2MCPA, ampicillin, kanamycin and tetracycline. Plasmid transfer occurred at low frequencies of about $10^{-6}$. The putative $P$. putida strains carrying R68.44 were checked for characteristic growth on King's A and B media. The transconjugants produced cream/white colonies with no pigment on King's A medium, characteristic of $P$. putida strains, whereas $P$. aeruginosa produced a green diffusible pigment. On King's B medium the transconjugants produced lime-green, yellowfluorescing colonies, again characteristic of $P$. putida and in contrast to $P$. aeruginosa which produced darker green, white/blue-fluorescing colonies. A number of transconjugants were screened for the presence of plasmid DNA, including the strain $P$. putida PPW1 selected for the mobilization studies, and were shown to contain a plasmid of the same size as that in the donor strain.

A comparison of the digests using restriction endonucleases Pst I and SmaI showed unexpected, significant differences between the plasmids in P. aeruginosa PAC174 and P.putida PPW1 (Fig. 1). This was a consistent modification since in two other independent matings using $P$. putida PP3 as recipient, the same changes in the digests were obtained. In view of the differences, the plasmid found in $P$. putida PPW1 was designated pUU1. The second largest fragment $(21.0 \mathrm{~kb})$ in the PstI digest of plasmid R68.44 was missing in the equivalent digest of plasmid pUU1 (Fig. 1 $a$ ). It was replaced by two additional fragments of sizes 15.0 and $11.7 \mathrm{~kb}$ in pUU1. Thus the combined size of the additional DNA was $5.7 \mathrm{~kb}$ greater than the replaced $21.0 \mathrm{~kb}$ fragment of R68.44. However, the complete size of pUU1 calculated from the PstI fragments was $61.7 \mathrm{~kb}$ compared with the size of R68.44 which was calculated to be $58.0 \mathrm{~kb}$ [this size for R68.44 includes the second copy of the $0.74 \mathrm{~kb}$ fragment identified by Riess et al. (1980)]. The difference of $3.7 \mathrm{~kb}$ was significantly smaller than the insert of DNA into the fragment of size $21.0 \mathrm{~kb}$ and was due to the concomitant loss of two PstI fragments at some time during the formation of pUU1 from R68.44. The loss of these two fragments $(1.3 \mathrm{~kb}$ and $0.74 \mathrm{~kb})$ with a total of $2.0 \mathrm{~kb}$ and the addition of the $5.7 \mathrm{~kb}$ insert accounted for the net increase in size of pUU1 compared with plasmid R68.44.

With restriction endonuclease $S m a \mathrm{I}$, the second largest fragment $(16.6 \mathrm{~kb})$ was also lost in plasmid pUU1 and replaced by a single, larger fragment of $20.0 \mathrm{~kb}$, giving an increase in size of $3.4 \mathrm{~kb}$ (Fig. $1 b$ ). This is comparable with the extra DNA $(5.7 \mathrm{~kb})$ determined from the PstI digestion. Furthermore, in agreement with the Pst I digestion data, one $S m a \mathrm{I}$ fragment of $2.0 \mathrm{~kb}$ was lost, resulting in a net increase in the size of plasmid pUU1 of $1.4 \mathrm{~kb}$.

\section{The mobilization of the fraction I dehalogenase gene into P. putida PaW340}

Pseudomonas putida PPW1 was mated on a membrane with $P$. putida PaW340 with selection for transconjugants on medium containing 2MCPA, tryptophan, ampicillin, kanamycin, streptomycin and tetracycline. Transconjugants were selected at a frequency of $1.3 \times 10^{-10}$ per donor cell. This compared with a frequency of $0.1 \times 10^{-6}$ to $1.3 \times 10^{-6}$ per donor cell for the transfer of plasmid pUU1 into $P$. putida PaW340 in the absence of selection for growth on 2MCPA. The transconjugants proved to be tryptophan auxotrophs and contained a plasmid; one was designated $P$. putida PPW 2.

Dehalogenase activity was demonstrated in P. putida PPW2 but the activity towards DCA was substantially lower than the activities in P. putida strains PP3 and PPW1 (Table 1). Indeed, the substrate activity ratios were indicative of an organism synthesizing only the fraction I dehalogenase, such as $P$. putida PP411-006, and compared favourably with the activity ratio for partially purified fraction I dehalogenase (Table 1). This was confirmed by discontinuous PAGE of $P$. putida strains PP3, PPW1 and PPW2 (Fig. 2). These results suggest the formation of a plasmid which carries $P$. putida chromosomal DNA encoding the fraction I dehalogenase gene.

Further evidence for the formation of such a plasmid was obtained by mating P.putida PPW2 with $P$. aeruginosa PAU2 as recipient and selecting for transfer of drug resistance markers. 
(a) Pst I restriction endonuclease digest
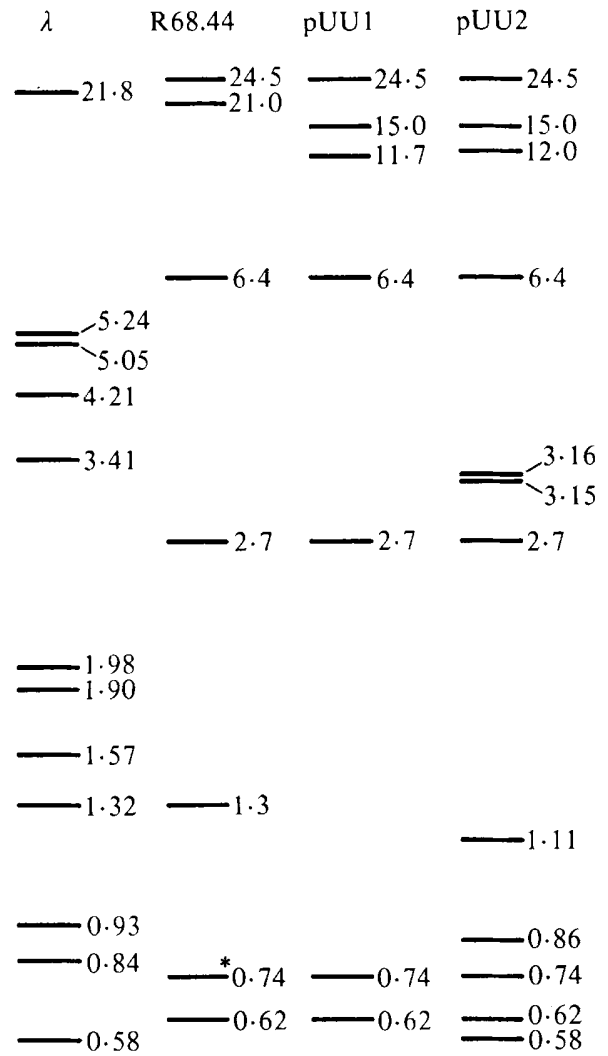

Total size $58 \cdot 00$

61.66

$70 \cdot 81$

Net increase in size

Inserted DNA

Deleted DNA (b) SmaI restriction endonuclease digest
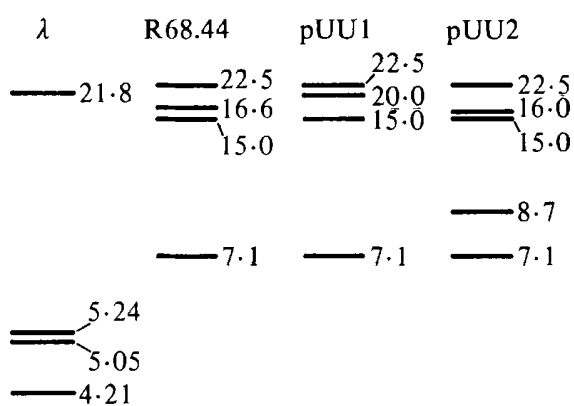

$-3.41$
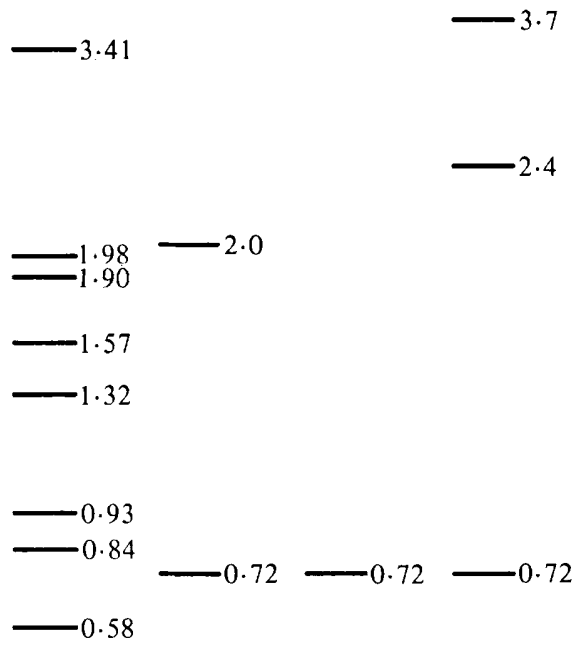

$\begin{array}{lcrr}\text { Total size } & 63.92 & 65.32 & 76.32 \\ \text { Net increase in size } & - & 1.40 & 11.00 \\ \text { Inserted DNA } & - & 3.40 & 11.00 \\ \text { Deleted DNA } & - & 2.00 & 0.00\end{array}$

Fig. 1. Restriction endonuclease digest fragment patterns for (a) enzyme PstI and (b) enzyme $S m a \mathrm{I}$ for plasmids R68.44, pUU1 and pUU2 in $P$. putida PPW2. The fragment sizes are given in $\mathrm{kb}$ by calculation from a double digest of $\lambda$ DNA with restriction endonucleases EcoRI and HindIII and using standard DNA fragment sizes given by Southern (1979). The asterisk indicates the position of two fragments of the same size.

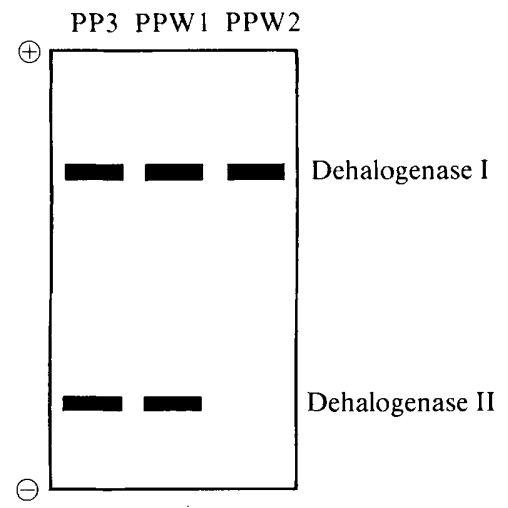

Fig. 2. Distribution of dehalogenases from P. putida strains PP3, PPW1 and PPW2 after separation by PAGE. 
Table 1. Dehalogenase specific activities and substrate activity ratios for various strains of $P$. putida and $P$. aeruginosa

\author{
Strain \\ P. putida PP3 \\ P. putida PPW1 \\ P. putida PPW2 \\ P. putida PP411-006†
}

Partially purified fraction I dehalogenase

\begin{tabular}{|c|c|c|c|}
\hline \multicolumn{4}{|c|}{$\begin{array}{l}\text { Dehalogenase specific activities } \\
{\left[\mu \mathrm{mol} \text { substrate } \mathrm{min}^{-1}(\mathrm{mg} \text { protein })^{-1}\right]^{*}}\end{array}$} \\
\hline MCA & DCA & 2MCPA & 22DCPA \\
\hline 0.45 & 0.63 & $0 \cdot 15$ & 0.08 \\
\hline$(1 \cdot 00)$ & $(1 \cdot 40)$ & $(0 \cdot 33)$ & $(0 \cdot 18)$ \\
\hline 0.32 & 0.40 & 0.14 & 0.08 \\
\hline$(1.00)$ & $(1 \cdot 28)$ & $(0 \cdot 44)$ & $(0 \cdot 26)$ \\
\hline 0.66 & 0.08 & 0.28 & 0.14 \\
\hline$(1.00)$ & $(0 \cdot 12)$ & $(0.42)$ & $(0.21)$ \\
\hline ND & ND & ND & ND \\
\hline$(1 \cdot 00)$ & $(0 \cdot 17)$ & $(0.49)$ & ND \\
\hline 0.62 & 0.07 & 0.40 & $0 \cdot 19$ \\
\hline$(1 \cdot 00)$ & $(0 \cdot 11)$ & $(0.65)$ & $(0 \cdot 31)$ \\
\hline
\end{tabular}

ND, Not determined.

* Numbers in parentheses are dehalogenase substrate activity ratios with respect to MCA.

$\dagger$ Data from Weightman et al. (1982).

$\ddagger$ Data from Weightman et al. (1979).

Transconjugants were selected at a frequency of $3.8 \times 10^{-4}$ per donor cell. Of these transconjugants $95 \%$ co-inherited the ability to grow on $2 \mathrm{MCPA}$ as the sole carbon and energy source. As additional evidence, plasmid pUU2 was obtained from P. putida PPW2 and transformed into $P$. aeruginosa PAO1162 and transformants selected on the basis of drug resistance. Fifty of the transformants were tested and all grew on defined medium containing 2MCPA. No colonies grew on control plates on which recipient cells alone had been spread.

\section{Restriction endonuclease digestion of plasmid pUU2 from $P$. putida PPW2}

Digestion of plasmid pUU2 with restriction endonucleases Pst I and SmaI revealed that fragments were generated in the same positions as the equivalent digestions for the parent plasmid, with the exception of one fragment in both cases (Fig. 1). For the PstI digestion the $11.7 \mathrm{~kb}$ fragment was missing whilst in the $S m a I$ digestion the $20.0 \mathrm{~kb}$ fragment was not present in pUU2 (Fig. 1).

There were, however, a number of new DNA fragments in plasmid pUU2 which were not present in plasmid pUU1. Using the restriction endonuclease $P_{s t} \mathrm{I}$, six extra bands were formed with sizes of $12.0,3.16,3.15,1.1,0.86$ and $0.58 \mathrm{~kb}$; and for the SmaI digestion four new fragments were detected with sizes of $16.0,8.7,3.7$ and $2.4 \mathrm{~kb}$ (Fig. 1). Thus, with these additional DNA fragments, plasmid pUU2 had a size of 70.8 to $76.3 \mathrm{~kb}$, depending on which restriction endonuclease was used for the size determination. This represented an increase of $9 \cdot 2$ to $11.0 \mathrm{~kb}$ as a result of the formation of the R-prime. The inserted DNA carrying the fraction I dehalogenase gene therefore had an additional four PstI sites and two SmaI sites.

\section{DISCUSSION}

The restriction endonuclease digest data for enzymes $P$ st I and SmaI were consistent with the previously published information (Riess et al., 1980; Leemans et al., 1980; Nayudu \& Holloway, 1981 ; Willetts et al., 1981) enabling the construction of a plasmid map showing the positions of the various restriction cleavage sites (Fig. 3). Plasmid R68.44 contained region I (Fig. 3) with two Pst I and one SmaI sites whereas plasmid pUU1 had lost this region; this was demonstrated by loss of two Pst I fragments totalling $2.0 \mathrm{~kb}$ and the equivalent loss of a single $S m a \mathrm{I}$ fragment of $2 \cdot 0 \mathrm{~kb}$ size. The region lost has previously been associated with the enhanced chromosomemobilizing capability of plasmid R68.44 and is probably the only difference with plasmid R68 which has no enhanced chromosome-mobilizing ability (Jacob et al., 1977; Riess et al., 1980; 


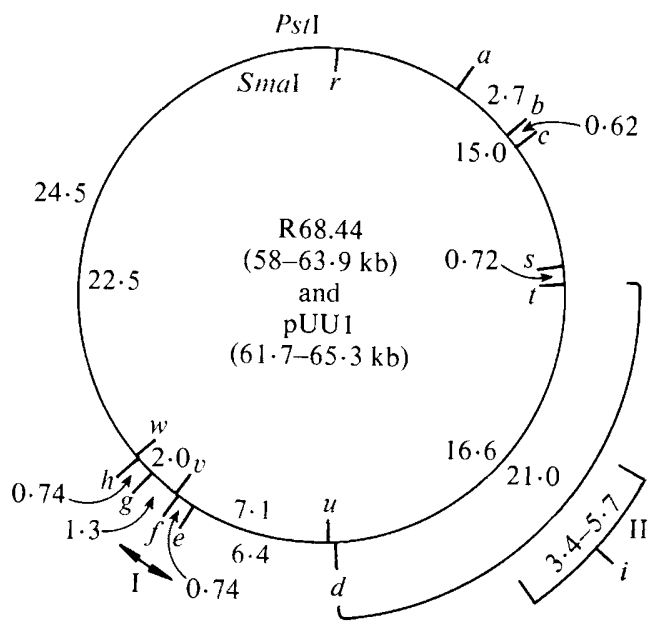

Fig. 3. Map of plasmids R68.44 and pUU1 showing the position of PstI and SmaI restriction endonuclease digestion sites. Segment I constitutes the region of IS21 (Willetts et al., 1981) which is present in R68.44 but not in pUU1. Segment II is present in pUU1 but not in R68.44; the position of the insertion is not precisely known but is located between restriction sites $d$ and $t$. The map of R68.44 is derived by inserting the sizes of restriction fragments $(\mathrm{kb})$ obtained in this study into the map of Riess $e t$ al. (1980).

Leemans et al., 1980; Willetts et al., 1981). Willetts et al. (1981) have designated this IS21 since its properties are similar to other transposable genetic elements. For example, it has been transposed to the pBR325-based vector pED815 at frequencies of approximately $2 \times 10^{-3}$. Furthermore, it can excise precisely at frequencies of approximately $2 \times 10^{-4}$, regenerating tetracycline resistance in plasmid pMO891 (Willetts et al., 1981). This latter capability explains the high degree of instability of the enhanced chromosome-mobilizing ability of plasmids R68.44 and R68.5 (Haas \& Holloway, 1976) and the ease with which plasmid pUU1 lost this region in the present study. In a number of independently isolated plasmids resulting from transfer of R68.44 from $P$. aeruginosa PAC174 to $P$. putida PP3, this region was repeatedly eliminated.

Another reproducible event, observed on several independent occasions when plasmid R68.44 was introduced into $P$. putida PP3, was the initial acquisition of 3.4 to $5.7 \mathrm{~kb}$ of new DNA, segment II. This was inserted in the overlapping regions of the $21.0 \mathrm{~kb} P$ stI fragment (generated between $P s t \mathrm{I}$ sites $c$ and $d$ ) and the $16.6 \mathrm{~kb} S m a \mathrm{I}$ fragment (generated between the SmaI sites $t$ and $u$ ) (Figs 1 and 3). Since the $21.0 \mathrm{~kb}$ Pst I fragment of plasmid R68.44 was replaced by two new fragments $(15.0$ and $11.7 \mathrm{~kb})$ in pUU1, the newly inserted DNA must contain a single, additional PstI site (site $i$, Fig. 3). The inserted DNA, however, does not contain an additional $S m a$ I site since the parent $16.6 \mathrm{~kb}$ fragment was replaced by a single, larger $S m a I$ fragment of size $20.0 \mathrm{~kb}$ in pUU1. The results do not yet enable segment II to be precisely located since neither the position of the Pst I site within the $5.7 \mathrm{~kb}$ fragment is known nor the orientation of the two new PstI generated fragments. The origin of this extra DNA in pUU1 is at present unknown, but the possibility that it represented a duplicated IS21 region (since its size is almost exactly double that of IS21) can be excluded because the region does not contain appropriate PstI and SmaI sites. We cannot exclude duplication of other regions of the parent plasmid but we consider it more likely that this addition represents 'foreign' DNA obtained from the $P$. putida chromosome.

The additional $9 \cdot 2$ to $11.0 \mathrm{~kb}$ of DNA inserted into plasmid pUU1 during the formation of the dehalogenase R-prime, plasmid pUU2, was inserted within the common PstI and SmaI DNA contained between sites $d$ (PstI site) and $t$ (SmaI site) (Fig. 3). This was determined on the basis of the loss of a single $S m a I$ band $(20 \cdot 0 \mathrm{~kb})$ which itself was a composite of the original R68.44 $16.6 \mathrm{~kb}$ fragment (between sites $t$ and $u$ ) and the added $3.4 \mathrm{~kb}$ to produce pUU1 which did not 
have any further SmaI sites (Fig. 3). This was confirmed by the PstI digest showing that the extra DNA of pUU2 was added into the fragment of $11.7 \mathrm{~kb}$ of pUU1 which had in turn been generated by the addition of segment II into the original PstI fragment between sites $c$ and $d$ (Fig. 3). The exact location of the dehalogenase-encoding DNA cannot be determined with precision from the present information; however, the results do demonstrate that this must be between PstI site $d$ and SmaI site $t$ (Fig. 3).

These results demonstrate the formation of an R-prime carrying the gene for a catabolic enzyme. Furthermore, it is clear that the mobilization of the fraction I dehalogenase gene was not linked topographically with the IS21 region implicated in the mobilization of other pseudomonad genes (Willetts et al., 1981). Although we cannot pinpoint the time at which the $2.0 \mathrm{~kb}$ (IS21) segment was eliminated, its absence in pUU1 suggests that the R-prime formation proceeded without the involvement of the duplicate IS21 region. It is also clear that the site of integration of the dehalogenase gene is near the smaller segment of foreign DNA originally inserted during the formation of pUU1 (segment II, Fig. 3). It is possible that this region acts as a site for recombination with chromosomal DNA and hence a focal point for mobilizing chromosomal DNA. An analogous situation has been described for R68 and R68.45-like plasmids in Escherichia coli where the derivative plasmids contained $1.2 \mathrm{~kb}$ of E. coli $\mathrm{K} 12$ chromosomal DNA, possibly transposable elements, and were shown to have enhanced chromosome-mobilizing ability (Holloway, 1979). However, if this 3.4 to $5.7 \mathrm{~kb}$ region is associated with chromosome-mobilization in P. putida PPW1, it does not appear to be very efficient since the dehalogenase gene was transferred at very low frequencies (approximately $\left.10^{-10}\right)$. In part this is due to the low rate of transfer of plasmids R68.44 and pUUl between the various strains of $P$. putida and $P$. aeruginosa used in this study (approximately $10^{-6}$ to $10^{-7}$ ). This contrasts with considerably higher rates of plasmid transfer demonstrated elsewhere. For example, Johnston et al. (1978) demonstrated frequencies of $10^{-2}$ for the transfer of R68.45 from Rhizobium leguminosarum to Rhizobium meliloti which was similar to the rates observed between different strains of $R$. leguminosarum (Beringer et al., 1978). Thus, making the adjustment for poor plasmid transfer, the frequency of dehalogenase gene mobilization is about $10^{-6}$ which is comparable with the poorer mobilization frequencies recorded (Holloway, 1979).

Finally, we cannot exclude mechanisms of R-prime formation which have nothing to do with enhanced chromosome-mobilizing capabilities. It is possible, for example, that the plasmids act as suitable vectors for transposable elements which leave the chromosome independently of any plasmid-determined mechanism. Indeed, preliminary evidence suggests that the dehalogenase genes of $P$. putida PP3 are borne on transposable elements (J. H. Slater, A. J. Weightman and B. G. Hall, unpublished observations).

We thank Andrea H. Filipiuk and Alison L. Weightman for expert assistance and Professor B. W. Holloway for constructive criticism of the manuscript. J.R.B. thanks the Natural Environment Research Council for a Research Studentship. J.H.S. acknowledges support from the Natural Environment Research Council for project grant no. GR/3/4199.

\section{REFERENCES}

Bagdasarian, M. \& Timmis, K. N. (1981). Host : vector systems for gene cloning in Pseudomonas. Current Topics in Microbiology and Immunology 96, 47-67.

Beringer, J. E., Hoggan, S. A.\& Johnston, A. W. B. (1978). Linkage mapping in Rhizobium leguminosarum by means of R-plasmid mediated recombination. Journal of General Microbiology 104, 201-207.

Berry, E. K. M., Allison, N., Skinner, A. J. \& COOPER, R. A. (1979). Degradation of the selective herbicide 2,2-dichloropropionate (Dalapon) by a soil bacterium. Journal of General Microbiology 110, 3945 .
Birnboim, H. C. \& Doly, J. (1979). A rapid alkaline extraction procedure for screening recombinant plasmid DNA. Nucleic Acids Research 7, 1513-1523.

Burge, W. D. (1969). Populations of Dalapondecomposing bacteria in soil as influenced by additions of Dalapon or other carbon sources. Applied Microbiology 17, 545-550.

DunN, N. W. \& Holloway, B. W. (1971). Pleiotrophy of $p$-fluorophenylalanine-resistant and antibiotic hypersensitive mutants of Pseudomonas aeruginosa. Genetical Research 18, 185-197.

Goldman, P., Milne, G. W. A. \& Keister, D. B. 
(1968). Carbon-halogen bond cleavage. III. Studies on bacterial halidohydrolases. Journal of Biological Chemistry 243, 428-434.

HaAS, D. \& Holloway, B. W. (1976). R-factor variants with enhanced sex-factor activity. Molecular and General Genetics 114, 243-251.

Hardman, D. J. \& Slater, J. H. (1981). Dehalogenases in soil bacteria. Journal of General Microbiology 123, 117-128.

HedGeS, R. W. \& JACOB, A. E. (1977). In vivo translocation of genes of Pseudomonas aeruginosa onto a promiscuously transmissible plasmid. FEMS Microbiology Letters 2, 15-19.

Holloway, B. W. (1979). Plasmids that mobilize bacterial chromosome. Plasmid 2, 1-19.

J ACOB, A. E., Cresswell, J. M. \& Hedges, R. W. (1977). Molecular characterization of the P-group plasmid R68 and variants with enhanced chromosome mobilizing ability. FEMS Microbiology Letters 1, 71-74.

Johnston, A. W. B., Setchell, S. M. \& Beringer, J. E. (1978). Interspecific crosses between Rhizobium leguminosarum and Rhizobium meliloti: formation of haploid recombinants and of R-primes. Journal of General Microbiology 104, 209-218.

Kawasaki, H., Tone, N. \& Tonomura, K. (1981). Plasmid-determined dehalogenation of haloacetates in Moraxella species. Agricultural and Biological Chemistry 45, 29-34.

Kawasaki, H., Hayashi, S., Yahara, H., Minami, F. \& Tonomura, K. (1982). Plasmid pUO2 determining haloacetate dehalogenase and mercury resistance in Pseudomonas species. Journal of Fermentation Technology 60, 5-11.

KING, A. \& PhILlips, I. (1978). The identification of pseudomonads and related bacteria in a clinical laboratory. Journal of Medical Microbiology 11, 165176.

Leemans, J., Villarroel, R., Silva, B., Van MoNTAGU, M. \& SCHELL, J. (1980). Direct repetition of a 1.2 Md DNA sequence is involved in site specific recombination by the $\mathrm{P} 1$ plasmid R68. Gene 10, 319328.

LitTle, M. \& Williams, P. A. (1971). A bacterial halidohydrolase: its purification, some properties and its modification by specific amino acid reagents. European Journal of Biochemistry 21, 99-109.

Miller, J. H. (1972). Experiments in Molecular Genetics. Cold Spring Harbor, New York: Cold Spring Harbor Laboratory.

NAYUdU, M. \& Holloway, B. W. (1981). Isolation and characterization of $R$-prime variants with enhanced chromosomal mobilization ability in Escherichia coli K12. Plasmid 6, 53-66.
Riess, G., Holloway, B. W. \& Puhler, A. (1980). R68.45, a plasmid with chromosome mobilizing ability, carries a tandem duplication. Genetical Research 36, 99-109.

Senior, E., Bull, A. T. \& Slater, J. H. (1976). Enzyme evolution in a microbial community growing on the herbicide Dalapon. Nature, London 263, 476-479.

Slater, J. H. (1978). The role of microbial communities in nature. In The Oil Industry and Microbial Ecosystems, p. 137. Edited by H. J. Sommerville \& K. F. Chater, London: Heyden.

Slater, J. H. \& Bull, A. T. (1982). Environmental microbiology: biodegradation. Philosophical Transactions of the Royal Society. Series B 297, 575-597.

Slater, J. H. \& Godwin, D. (1980). Microbial adaptation and selection. In Contemporary Microbial Ecology, pp. 137-160. Edited by D. C. Ellwood, J. N. Hedger, M. J. Latham, J. M. Lynch \& J. H. Slater. London: Academic Press.

Slater, J. H., Lovatt, D., Weightman, A. J., Senior, E. \& Bull, A. T. (1979). The growth of Pseudomonas putida on chlorinated aliphatic acids and its dehalogenase activity. Journal of General Microbiology 114, $125-136$.

Southern, E. M. (1979). Gel electrophoresis of restriction fragments. Methods in Enzymology 68, 152-176.

Weightman, A. J. \& Slater, J. H. (1980). Selection of Pseudomonas putida strains with elevated dehalogenase activities by continuous culture growth on chlorinated alkanoic acids. Journal of General Microbiology 121, 187-193.

Weightman, A. J., Slater, J. H. \& Bull, A. T. (1979). The partial purification of two dehalogenases from Pseudomonas putida PP3. FEMS Microbiology Letters 6, 231-234.

Weightman, A. J., Weightman, A. L. \& Slater, J. H. (1982). Stereospecificity of 2-monochloropropionate dehalogenation by the two dehalogenases of Pseudomonas putida PP3: evidence for two different dehalogenation mechanisms. Journal of General Microbiology 128, 1755-1762.

Wheatcroft, R. \& Williams, P. A. (1981). Rapid methods for the study of both stable and unstable plasmids in Pseudomonas. Journal of General Microbiology 124, 433-437.

Willetts, N. S., Crowther, C. \& Holloway, B. W. (1981). The insertion sequence IS21 of R68.45 and the molecular basis for mobilization of the bacterial chromosome. Plasmid 6, 30-52. 